\title{
NUTRIENT ANALYSIS OF SOME FRESH WATER FISH
}

\author{
S. WIMALASENA and M.N.S. JAYASURIYA \\ Department of Chemistry, University of Kelaniya, Kelaniya.
}

(Received: 17 April 1995; accepted: 01 December 1995)

\begin{abstract}
Edible flesh, moisture, carbohydrate, lipid, protein, ash, sodium, potassium, calcium, phosphorus and iron content of commonly eaten fresh water fish namely Heteropneustes fossilis (E. Stinging cat fish, S. Hunga, T. Shunken), Anabas testudineus (E. Climbing perch, S. Kavaiya, T. Kavaiyan), Oreochromis mossambicus (Tilapia), Ophicephalus striatus (E. Snakehead, S. Lulla, T. Viral) and Glossogobius giuris (E. Goby, S. Weligouva, T. Uluvai) were determined. Protein, carbohydrate, calcium, phosphorus and iron content were highest in stinging cat fish while goby had the highest amount of potassium and sodium. Climbing perch had the highest lipid content.
\end{abstract}

Key words: Anabas testudineus, fish, fresh water fish, Glossogobius giuris, Heteropneustes fossilis, nutrients, Ophicephalus striatus; Oreochromis mossambicus.

\section{INTRODUCTION}

Fish have a low calorific value and low fat content but a high protein content. Further, n-3 fatty acids found in fish prevent coronary heart diseases. ${ }^{1}$ Studies on the chemical composition of fish have been carried out on marine fish, but analyses carried out on fresh water fish are rare.

This study was undertaken to determine whether fresh water fish could be recommended as a less expensive substitute for marine fish, particularly in combating protein malnutrition in early childhood, preventing heart diseases and in cases of deficiency of minerals and vitamins. A study of the nutrient values of fresh water fish is important in fish processing industries such as production of dry fish, canning and preparation of fish meals.

This study reports the moisture, carbohydrate, protein, lipid, ash, potassium, sodium, calcium, phosphorus and iron content in five commonly eaten varieties of fish namely Heteropneustes fossilis (E. Stinging cat fish, S. Hunga, T. Shunken), Anabas testudineus (E. Climbing perch, S. Kavaiya, T. Kavaiyan), Oreochromis mossambicus (E. Tilapia, S. Tilapia, T. Tilapia), Ophicephalus striatus (E. Snakehead, S. Lulla, T. Viral), Glossogobius giuris (E. Goby, S. Weligouva, T. Uluvai). 


\section{METHODS AND MATERIALS}

Sampling of fish for analysis : Stinging cat fish and climbing perch used in the analyses were from Ranawa tank, Narammala, tilapia and goby were from Bathalagoda tank, Ibbagamuwa and snakehead was from Magala tank, Nikaweratiya.

Fish samples purchased at three different times were analyzed for each species. Random samples from a mixture of flesh from 2 - 8 similar sized fish were taken for the analyses. Fish were cleaned and dried with blotting papers. Edible parts of the fish (i.e. parts without scales, head, internal organs and bones) were taken for the analyses.

Determination of moisture ${ }^{2}$ : The amount of water in the samples $(10 \mathrm{~g})$ was measured using Dean and Stark apparatus with distilled toluene $(250 \mathrm{ml})$ as solvent.

Determination of carbohydrates ${ }^{2}$ : The edible flesh (2.5g) was stirred with distilled water $(10 \mathrm{ml})$ and $52 \%$ perchloric acid $(13 \mathrm{ml})$ for $20 \mathrm{~min}$. The contents were diluted to $100 \mathrm{ml}$, filtered into a $250 \mathrm{ml}$ volumetric flask and made upto the mark. The diluted filtrate $(1.0 \mathrm{ml})$ was heated with $1 \% \mathrm{w} / \mathrm{v}$ anthrone reagent in sulphuric acid for $20 \mathrm{~min}$. and the absorbance at $630 \mathrm{~nm}$ was measured in a Shimadzu UV160 spectrometer. The concentration of glucose in the sample was calculated using a standard curve.

Determination of lipid ${ }^{2}$ : The flesh $(5 \mathrm{~g})$ was extracted with chloroform $(5 \mathrm{ml})$ and methanol $(10 \mathrm{ml})$ using chloroform - methanol extraction method. The amount of lipid was calculated from the residue remaining after evaporating the chloroform layer.

Determination of crude protein ${ }^{2}$ : The edible flesh $(2 \mathrm{~g})$ was digested with anhydrous potassium sulphate $(15 \mathrm{~g})$, copper sulphate pentahydrate $(0.5 \mathrm{~g})$ and concentrated sulphuric acid ( $25 \mathrm{ml})$. Amount of protein in the digested sample was determined using Kjeldahl method.

Determination of $a s h^{2}$ : The edible flesh $(5 \mathrm{~g})$ was ignited in a muffle furnace at $550^{\circ} \mathrm{C}$ to a constant weight.

Determination of sodium, potassium \& calcium ${ }^{2}$ : The ash was digested with $3 \mathrm{M}$ hydrochloric acid $(15 \mathrm{ml})$ and filtered. Emissions for calcium, potassium and sodium were measured at $620 \mathrm{~nm}, 768 \mathrm{~nm}$ and $589.6 \mathrm{~nm}$ respectively using a Corning-410 flame photometer. 


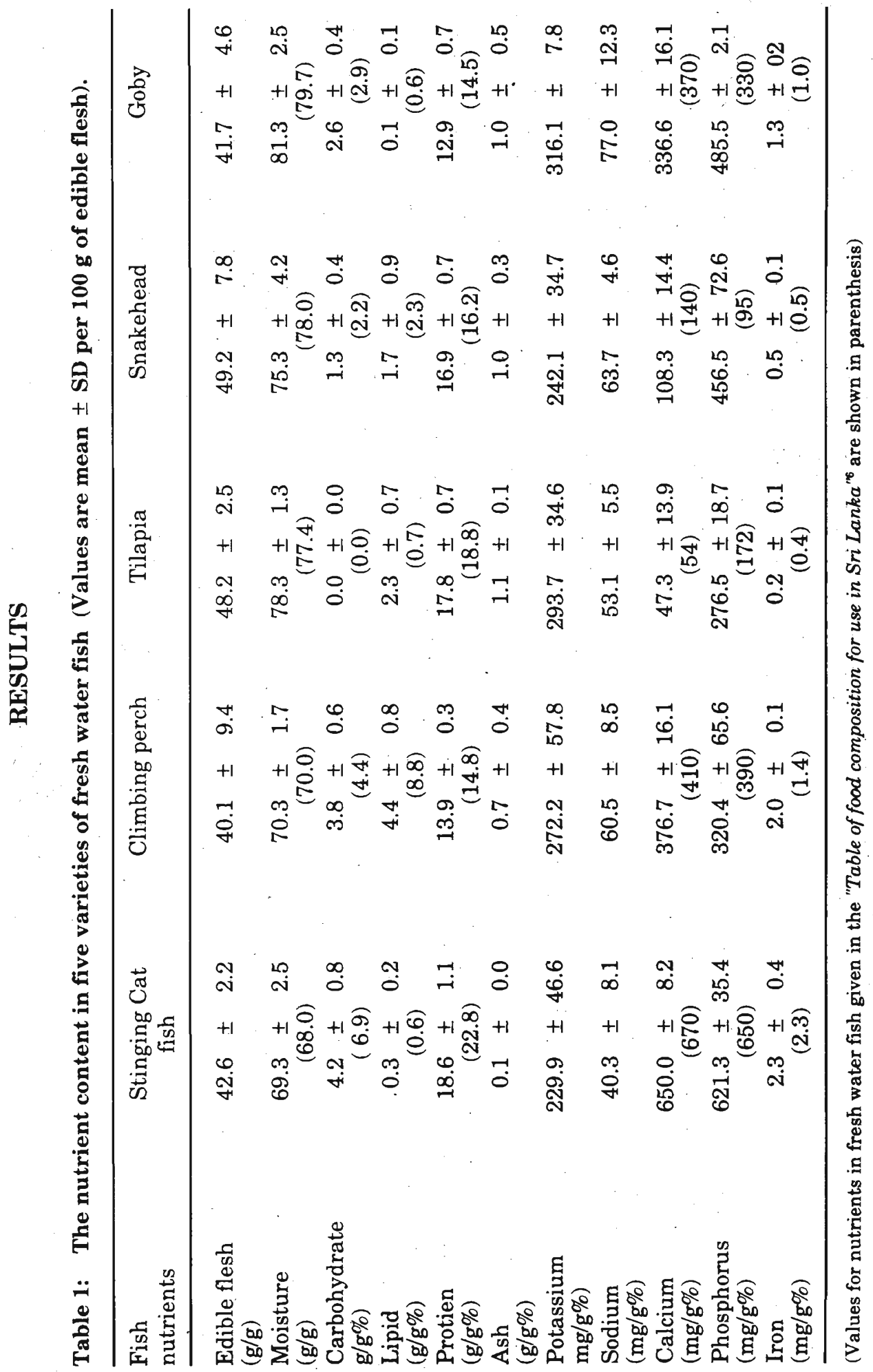


Determination of phosphorus ${ }^{3}$ : The ash was digested with hydrochloric acid and diluted sample $(10 \mathrm{ml})$ was treated with molybdovanadate reagent $(.5 \mathrm{ml})$. The amount of phosphorus was calculated from the absorbance at $400 \mathrm{~nm}$.

Determination of iron ${ }^{4}$ : The ash was digested with hydrochloric acid and diluted sample $(10 \mathrm{ml})$ was treated with $10 \%$ hydroxylamine hydrochloride $(1 \mathrm{ml})$, acetate buffer of $\mathrm{pH} 4.5$ and $0.1 \%$ orthophenanthroline solution $(1 \mathrm{ml})$. The absorbance at $510 \mathrm{~nm}$ was measured. The amount of acetate buffer that has to be added to adjust the $\mathrm{pH}$ to 3.5-4.5 was predetermined using the above solution (10ml) diluted to $25 \mathrm{ml}$.

Table 2: Mean weight, mean total length and mean standard length of fish analysed \pm SD.

\begin{tabular}{lccc}
\hline Fish & $\begin{array}{c}\text { Mean weight } \\
(\mathrm{g})\end{array}$ & $\begin{array}{c}\text { Mean total } \\
\text { length(cm) }\end{array}$ & $\begin{array}{c}\text { Mean standard } \\
\text { length(cm) }\end{array}$ \\
\hline $\begin{array}{l}\text { Stinging cat fish } \\
\text { Climbing perch }\end{array}$ & $\begin{array}{l}37.2 \pm 4.2 \\
\text { Tilapia }\end{array}$ & $18.0 \pm 1.0$ & $15.6 \pm 1.5$ \\
Snake head & $59.2 \pm 12.3$ & $11.4 \pm 0.9$ & $9.0 \pm 1.0$ \\
Goby & $112.0 \pm 14.3$ & $24.6 \pm 1.6$ & $21.3 \pm 1.4$ \\
\hline
\end{tabular}

Table 3: Nutrient content of fresh water fish in Sri Lanka (previous analyses).

\begin{tabular}{lccccc}
\hline Fish & Moisture & Protein & Lipid & Carbohydrate & Ash \\
\hline $\begin{array}{l}\text { Tilapia } \\
\text { (g/g\% fresh fish) }\end{array}$ & 79.43 & 76.65 & 4.05 & 11.66 & 6.92 \\
$\begin{array}{l}\text { Stinging cat fish } \\
\text { (\%edible flesh) }\end{array}$ & 79.8 & 17.2 & 1.9 & 0.7 & - \\
\hline
\end{tabular}




\section{DISCUSSION}

The moisture, carbohydrates, proteins, lipids and ash content of marine fish are reported as $66-84 \%, 0-2.9 \%, 15-20 \%, 0.1-20 \%, 0.8-2 \%$ respectively. ${ }^{5}$ Comparing these values with the results obtained in the present study it is observed that in fresh water fish the carbohydrate content is higher while the protein, lipids, and ash contents are lower than those of marine fish. Because fresh water fish are less expensive than marine fish, they may provide better nutrient value for money spent. In most cases the values obtained in the present study for the nutrients of fresh water fish were not comparable with the values reported in the Tables of food composition for use in Sri Lanka and this may be due to differences in sampling techniques which were not reported in the previous study. ${ }^{6}$

Processed products from fresh water fish like dried fish, salted fish, canned fish are not produced in marketable quantities. Hence the chemical analyses reported here will be useful in the fish processing industry. The moisture content indicates the amount of drying necessary to produce dry fish. Oil in dried fish tends to give an unpleasant odour, colour and taste with time. Hence less oily fish are suitable for drying. This study shows that stinging cat fish which has the least amount of water and a low fat content will be the most suitable fish for making dried fish. For canning, oily fish are suitable, hence climbing perch could be recommended. Conversion of fish waste and unpopular fish into fish meal is important in fish processing industry. Though fish meal is at present used for animal feeding, a meal could be obtained to suit human consumption by an appropriate method. Fish meal should contain the least amount of oil to prevent rancidity on storage. Moisture content will give an indication of the amount of drying necessary. Hence from the study of nutrients in fresh water fish, manufacturers will be in a position to determine the type of equipment and method of processing best suited to produce an acceptable fish meal.

\section{Acknowledgement}

We thank Dr. U.S.Amerasingha, Department of Zoology, University of Kelaniya for help in identifying the fish.

\section{References}

1. Kinsella J.E. (1988). Fish as sea food, nutritional implications and quality issues. Food Technology 42(5):146 -148.

2. Osborne D.R. \& Voogt P. (1978). The analysis of nutrients in food. pp. 109172. Academic Press, London. 
3. Official methods of analysis (1990). (Ed.S. Williams). 15th ed. pp. 916. Association of Official Analytical Chemists, Washington D.C.

4. Official methods of analysis (1990). (Ed. S. Williams). 15th ed. pp. 778. Association of Official Analytical Chemists, Washington D.C.

5. Jacquat R. (1961). Fish as food. Vol.1:(Ed. G. Borgstrom). pp. 146. Academic Press, New York.

6. Perera W.D.A., Jayasekara P.M. \& Thaha S.Z. (1979). Tables of food composition for use in Sri Lanka. pp. 19-24. Supreme Printers, Sri Lanka.

7. de Silva S.S. \& Rangoda M. (1979). Some chemical characteristics of fresh \& salt dried Tilapia mossambica petess. Journal of National Science Council of Sri Lanka 7(1) : 19-27

8. Pieris T.S.S.\& Gregro J.(1973). Chemical analysis of some Sri Lankan fishes. Bulletin of Fisheries Research Station Sri Lanka 24: 1-12. 